\title{
Ambigüidade Gerada pela Homonímia: Revisitação Teórica, Linhas limítrofes com a Polissemia e Proposta de Critérios Distintivos
}

(Ambiguity Generated for the Homonymy: Theoretical Revisitation, Bordering Lines with the Polisemy and Proposal of Distinctive Criteria)

Claudia ZAVAGLIA (UNESP/IBILCE)

ABSTRACT: This paper is an attempt to describe and to discuss the phenomenon of homonymy in Brazilian Portuguese as an ambiguity present in a natural language, by means of a theoretical revisitation to several authors and in confrontation with polisemy. It is also intended, besides conceptually redefining homonymy, to propose distinctive semantic criteria for this linguistic phenomenon, such as the semic analysis, the field lexicon, the use of crystallized expressions and the occurrence of specify features. KEY-words: Ambiguity; Homonymy; Polisemy; Semantic criteria .

RESUMo: O presente trabalho almeja expor o fenômeno da homonímia no português do Brasil, enquanto ambigüidade presente em uma língua natural, por meio de uma revisitação teórica em diversos autores e em confronto com a polissemia. Ademais, pretende-se, além de redefinir conceitualmente a homonímia, propor critérios semânticos distintivos para esse fenômeno lingüístico, tais como a análise sêmica, o campo léxico, o uso de expressões cristalizadas e a ocorrência de traços especificadores.

Palavras-Chave: Ambigüidade; Homonímia; Polissemia; Critérios semânticos.

\section{Ambiguiidade}

Entender e explicar como uma língua natural é adquirida por um ser humano a partir do seu nascimento tem motivado várias pesquisas realizadas por estudiosos de diferentes formações acadêmicas, como lingüistas e psicólogos, há várias décadas, e por filósofos desde a Antigüidade Clássica. Tal preocupação impulsiona os estudiosos a tecerem caminhos de pesquisa das mais variadas espécies proporcionando, desse modo, o aparecimento de diversas teorias. Essas pretendem, cada uma a seu modo, abarcar as explicações para a aquisição da linguagem bem como defini-la.

$\mathrm{Na}$ década de 40, acreditava-se que os estudos psicológicos não eram 
científicos porque não eram baseados em estudos empíricos. A partir de tal concepção, originou-se o Behaviorismo ou Teoria do comportamento que baseava seus estudos em métodos empíricos, ou seja, observáveis. O cientista passou a ser um observador de fenômenos externos que poderiam ser manipulados e medidos em laboratórios objetivamente, não dando margem a quaisquer manifestações subjetivas.

B.F. Skinner (1957) realizou a primeira tentativa de estudar a linguagem sob o ponto de vista behaviorista, apresentando a teoria do comportamento aplicada ao aprendizado de línguas. A linguagem passou a ser estudada apenas em termos daquilo que poderia ser observado, rejeitando-se noções mentalistas como idéias ou significados. O termo "língua" foi abandonado e passou a utilizar-se para tal, "comportamento verbal". O aprendizado passou a ser concebido, então, como aquisição de comportamento, sob uma relação de estímulos e respostas: uma criança só poderia compreender e produzir uma sentença se ela já a tivesse escutado antes, ou seja, somente após um treinamento mecânico a criança poderia produzir as respostas desejadas.

Noam Chomsky (1959) rebateu os argumentos do tratado de Skinner quando afirmou que a linguagem é produzida por processos mentais que são governados por princípios específicos e determinados geneticamente. A criança não é condicionada a aprender uma língua, mas já nasce programada para tal. A capacidade da linguagem possui uma característica básica que é a criatividade, a partir da qual uma criança é capaz de produzir e compreender frases que nunca ouviu antes. Enfim, para Chomsky, a criança possui uma capacidade inata de adquirir uma língua, isto é, ela já é possuidora da faculdade para a linguagem e, portanto, será capaz de reconhecer as regras gramaticais da língua pertencente ao ambiente linguiístico no qual está inserida. Desse modo, a partir de tais contra-argumentos, Chomsky, inaugurou o que hoje se chama de Inatismo como sendo uma teoria para a aquisição da linguagem.

Alguns pesquisadores influenciaram-se pelos argumentos de Chomsky, adotando uma posição contrária ao behaviorismo, mas não assumiram, como ele, que uma gramática não fosse aprendida e que, portanto, fosse totalmente inata a uma criança. Contra-argumentaram em favor do desenvolvimento cognitivo das crianças, que poderia ser a base para a aquisição da gramática. A partir de então, pesquisadores cognitivistas dirigiram suas pesquisas para a aquisição da linguagem, levando em consideração o crescimento conceitual do conhecimento das crianças. Tal abordagem focalizou um período pré-lingüístico para o aprendizado da linguagem da criança, partindo do princípio que crianças constroem noções básicas como objetos, ações, causalidade e relações espaciais antes do aprendizado lingüístico e, deste modo, 
vão construindo um "conhecimento" de mundo anterior à sua manifestação verbal. Segundo tal visão, o desenvolvimento inicial de noções lexicais, morfológicas e sintáticas é um processo de aprendizado que relaciona formas linguiísticas a conceitos preestabelecidos no período pré-lingüístico da criança. Essa abordagem, chamada de mentalista, surgiu com o intuito de rebater o inatismo de Chomsky, oferecendo assim, uma nova alternativa para o aprendizado e uma nova teoria para a aquisição da linguagem, a saber: o Cognitivismo.

Enquanto teoria da aquisição da linguagem, o cognitivismo nasceu a partir do construtivismo de Piaget e considera a existência universal de um estágio de desenvolvimento intelectual que precede a linguagem; admite a existência de uma simetria lógico-temporal entre linguagem e pensamento, na qual a criança possui uma intenção comunicativa antes mesmo de conseguir produzir uma frase completa, ou seja, há um pensamento na mente da criança, e ela não consegue traduzi-lo em linguagem; reconhece a existência universal de relações semânticas básicas (na fase telegráfica e na fase holofrástica) em que as primeiras palavras das crianças são reflexos de relações semânticas em várias línguas e proclama que a compreensão de mundo da criança precede a sua produção lingüística.

Para Chomsky (1988), o ser humano é capaz de distinguir se uma frase é bem feita e verificável em uma determinada língua sem que tenha tido uma experiência de mundo específica para tal. Existiriam princípios universais na sua mente que o levariam a uma gramática universal que determinaria que a construção correta é $O$ menino é inteligente e não Menino o inteligente é. O ser humano possui "intuições" sobre as propriedades e formalidades das sentenças que o levam a um conhecimento profundo de uma língua (capacidade essa que seria dada a um estudioso de uma língua) e que permitem que ele resolva ambigüidades em sentenças sem que as tenha aprendido um dia. Assim, o ser humano possuiria uma capacidade de linguagem determinada geneticamente que o levaria a satisfazer condições ambíguas em certas sentenças ou a construí-las de um certo modo e não de outro (regras de produção e compreensão de frases gramaticais).

Para a ilustração do fenômeno, considerem-se as seguintes frases (PiatelliPalmarini 1983):

(a) Paulo escreveu um livro.

(b) $\mathrm{O}$ livro pesa $2 \mathrm{Kg}$.

Em (a) temos que o referente da palavra livro é abstrato, enquanto que em (b), é concreto. Desse modo, o uso da palavra livro gera ambigüidade, já que pode ser empregado tanto em um uso abstrato como em um concreto. 
Neste caso, tem-se o fenômeno da ambigüidade sistemática que faz parte da estrutura sintática de uma língua. As frases (a) e (b) podem se combinar e gerar a seguinte construção: (c) Paulo escreveu um livro que pesa $2 \mathrm{Kg}$ na qual tem-se tanto o uso abstrato quanto o concreto da palavra livro empregados em uma frase bem formada e totalmente possível dentro dos padrões sistemáticos da língua portuguesa.

No caso da palavra livro, tem-se uma única forma que comporta um campo de significação fixo, o que possibilita a relativização das sentenças. A ambigüidade, neste caso, é totalmente estrutural, ou seja, sintática, e não pertence a uma propriedade idiossincrásica da palavra livro. O ser humano seria então, dotado de uma capacidade inata para perceber e distinguir a ambiguiidade existente entre os usos abstratos e concretos de uma palavra e desfazer tal ambigüidade, sempre que possível, através da relativização das sentenças.

Ainda como ilustração do fenômeno, consideremos as frases:

(d) Paulo usou o macaco do seu carro ontem.

(e) $\mathrm{O}$ macaco engordou $2 \mathrm{Kg}$.

Se fizermos a relativização das sentenças teremos a seguinte frase:

(f) Paulo usou o macaco do seu carro ontem que engordou $2 \mathrm{Kg}$.

Neste caso, estamos diante de uma frase mal formada semanticamente no português, e o encaixamento das sentenças não possibilita resolver o caso da ambigüidade existente entre o uso concreto e o uso abstrato da palavra macaco, dado que temos uma única forma com dois significados diferentes (instrumento mecânico e animal).

Segundo a ótica linguiística, a ambigüidade define-se em função das regras gramaticais. E assim, quando uma frase possibilita duas interpretações semânticas ou sintáticas, ela é considerada ambígua. Desse modo, temos a ambigüidade léxica gerada pela homografia que pode ser morfo-semânticocategorial: "A casa é bonita" / "Ela casa amanhã", exclusivamente semântica: "Sentei-me no banco do jardim" / "Fui ao banco sacar dinheiro" ou sintática: "Entrei no carro andando".

Segundo Ullmann (1964), lingüisticamente, existem três tipos principais de ambigüidade: fonética, gramatical e lexical. A ambigüidade fonética resulta da estrutura fonética da frase, isto é:

uma vez que a unidade acústica da linguagem seguida é o grupo pronunciado sem interrupção, e não a palavra individual, pode acontecer que dois daqueles grupos formados por palavras diferentes se tornem homônimos e 
assim potencialmente ambíguos (...) Em inglês, por exemplo, houve antigamente um substantivo near que significava "rim", (...) mas caiu depois em desuso porque a near podia confundir-se com an ear [uma orelha]. (Ullmann 1964:323-324)

Nesse sentido, em português, temos como pares de exemplo1: [agosto, oitavo mês do ano / a gosto, locução adverbial que significa "à vontade"]; [enquanto, conjunção que significa "no tempo em que"; "ao passo que" / em quanto, locução interrogativa: "Em quanto tempo ficará pronto o almoço?']; [envolta (forma feminina do particípio passado do verbo envolver) / em volta, locução adverbial que significa "em torno, ao redor"].

Por sua vez, a ambigüidade gramatical pode ser originada de dois modos: (i) pela ambigüidade de formas gramaticais e/ou (ii) pela ambigüidade da estrutura da frase. Em (i) temos o caso de prefixos e sufixos que possuem mais de um significado e, por isso, são ambíguos ou aqueles que são, por natureza, homônimos:

o sufixo -able não significa a mesma coisa em desiderable [desejável] ou readable [legível] que em eatable [comestível], knowable [conhecível], debatable [debatível] (...) O prefixo in-, que significa "em, dentro de, em direcção a, sobre" (por exemplo indent [entalhe], inborn [inerente], inbreeding [engendrar], inflame [inflamar]), tem um homônimo no prefixo in- que exprime negação ou privação (por exemplo inappropriate [inapropriado], inexperienced [inexperiente], inconclusive [inclonclusivo]). (Ullmann 1964:324)

Já em (ii) temos a possibilidade da ambigüidade por meio da "frase equívoca (anfibologia)" como nomeia Ullmann. Neste caso, a combinação de palavras que não são ambíguas possibilita a interpretação de dois ou mais modos diversos da frase. Para tanto, citamos o exemplo clássico desse tipo de ambigüidade estrutural, a saber: Vi a menina no jardim com o telescópio. Ambigüidades desse tipo poderão ser desfeitas pelo contexto ou pela entonação da frase em um discurso.

Em contrapartida, a ambiguiidade lexical é um dos fatores mais importantes dentre os fatores de ambigüidade presentes em uma língua. Com efeito, a "polivalência das palavras", tomando emprestado o termo de Ullmann (1964), assume duas formas diferentes: a polissemia e a homonímia. Para esse mesmo autor (1964:354), a polissemia pode conduzir à ambigüidade em três situações diferentes: (i) no contato entre as línguas, (ii) no uso técnico e científico e (iii) na fala vulgar. Em (i), a ambigüidade é ocasionada pelo empréstimo semântico de uma língua estrangeira, que leva à polissemia de 
uma palavra; em (ii) a reutilização de termos que outrora foram definidos com precisão, implica em novas definições do mesmo termo, levando-o a desenvolver mais de um sentido. Além disso, uma palavra ambígua de uso comum, quando introduzida em um contexto técnico e científico, também ocasionará confusões e equívocos no seu uso. Em (iii), a ambigüidade é ocasionada quando uma palavra produz dois ou mais sentidos em um mesmo contexto.

Segundo Dias da Silva (1996:102), a ambigüidade das formas lingüísticas pode ser local ou global: "a ambigüidade é global quando toda a seqüência de palavras, que compõem a frase, projeta mais de uma estrutura oracional gramaticalmente bem-formada potencial". Para demonstrar tal tipo de ambigüidade estrutural, o autor retoma frase clássica do inglês John saw the woman in the park with a telescope cujas interpretações ${ }^{2}$ podem ser:

1. João estava no parque e viu a mulher através de um telescópio.

2. João estava no parque e viu que a mulher tinha um telescópio.

3. João viu a mulher que estava no parque através de um telescópio.

4. João viu que a mulher que estava no parque tinha um telescópio.

Além desse exemplo, existem, segundo o autor, mais quatro tipos de ambigüidade, a saber: lexical, temática, referencial e pragmática.

As ambigüidades lexicais podem se manifestar por meio de três fenômenos: polissemia, homonímia e categorização gramatical. As ambigüidades categoriais dizem respeito a uma mesma forma lexical que pertence a classes sintáticas distintas: cara (adjetivo e substantivo), prova (substantivo e verbo), etc. As "ambigüidades temáticas ocorrem quando uma mesma preposição sinaliza funções temáticas diferentes. Por exemplo, na frase Maria trouxe um carro para Pedro, a preposição para pode introduzir o DESTINATÁRIO ou o BENEFICIÁRIO da ação" (Dias da Silva 1996:104). O mesmo autor chama esse tipo de ambigüidade de Homonímia Temática.

Por sua vez, as ambigüidades pragmáticas são causadas pela ausência de correspondência um-a-um entre forma gramatical e função comunicativa de uma expressão lingüística (Dias da Silva 1996:105). Assim, frases como [Copie.] e [Quem você conheceu?] podem preencher funções retóricas diferentes como pontua Dias da Silva (1996:105):
a. Fazer um pedido:
Copie, por favor.
b. Ameaçar:
Copie, que eu te dou zero.
c. Reclamar:
Copie! É só isso que sabe falar!
d. Solicitar Informação:
Quem você conheceu?
e. Expressar surpresa:
Quem você conheceu!? 
As ambigüidades referenciais são causadas pela possibilidade de preenchimento de valores referenciais por mais de um referente. Segundo Dias da Silva (1996:104): "na frase Coloquei o pão sobre o balcão e o comi, tanto o referente de o pão quanto o referente de o balcão estão sintaticamente 'autorizados' para 'preencher' o valor do pronome $o$ ".

A ambigüidade é local "quando apenas partes da seqüência de palavras que integram a frase projetam estruturas gramaticalmente bem formadas. Por exemplo, a frase A empresa que comprou a Universal vendeu a Borland poderia ser erroneamente analisada pela máquina como $A$ Universal vendeu a Borland" (Dias da Silva 1996:105).

Dias da Silva (1996) enfatiza, ainda, que a ambigüidade tanto das formas quanto das funções lingüísticas se manifesta em todos os níveis de análise: morfológico, sintático, semântico e pragmático-discursivo.

Cabe ressaltar que o fenômeno da ambigüidade existe somente para o receptor da mensagem, ao passo que para seu emissor a mensagem não é de forma alguma ambígua. O emissor da mensagem sabe exatamente qual é o seu referente, o seu conteúdo e o seu propósito; a interpretação do item lexical (ou da frase emitida) pelo destinatário é que ocasiona a ambigüidade.

Por fim, a ambigüidade pode atuar como um artifício estilístico, e ser intencional, em textos literários, poéticos, publicitários, fraseologias, provérbios, expressões idiomáticas, etc. Nesses casos, a polissemia e a homonímia são fenômenos produtivos de jogos de palavras que enriquecem o conteúdo textual, revelando-se uma riqueza da expressão lingüística.

\section{Polissemia}

Segundo Ullmann (1964), "a polissemia é um traço fundamental da fala humana, que pode surgir de maneiras múltiplas" (p.331). O autor cita cinco procedências que poderiam explicitar o fenômeno da polissemia em uma língua. São elas:

(i) Mudanças de aplicação, ou seja, um dado item lexical adquire um maior número de sentidos graças ao deslocamento de emprego que ele abarca num determinado período de uso. De fato, as ramificações do significado de uma palavra podem ocorrer dependendo do uso combinado com a outra palavra que a acompanha. Por exemplo: um adjetivo $X$ adquire os significados $y 1, y 2, y 3$ quando acompanhado por um substantivo que se refere a objetos concretos. Por sua vez, o adjetivo $X$ adquire os significados $z 1, z 2, z 3$ quando acompanhado por um substantivo que se refere a pessoas, e assim por diante;

(ii) Especialização num meio social, ou seja, as palavras adquirem signifi- 
cados diversos e específicos dependendo do seu campo de ação e atuação. O autor cita Bréal que diz: "Em todas as situações, em todos os ofícios ou profissões, escreve ele, há uma certa idéia que está tão presente na mente de cada um, tão claramente implicada, que parece desnecessário declarála quando se fala3" (Ullmann, 1964:334);

(iii) Linguagem figurada, isto é, quando uma palavra pode adquirir um ou mais sentidos figurados sem que haja a perda do seu significado original; os significados convivem lado a lado e não se confundem. Ullmann (1964) diz que "esta possibilidade de transposição metafórica é fundamental para a actividade da língua" (p. 338) e cita os dizeres do filósofo Urban:

$\mathrm{O}$ facto de um signo poder designar uma coisa sem deixar de designar outra, o facto de que, por ser um signo expressivo da segunda tenha também de o ser para a primeira, é precisamente o que faz da linguagem um instrumento de conhecimento. Esta "tensão acumulada" das palavras é a origem fecunda da ambigüidade, mas é também a origem dessa predicação analógica, causa única do poder simbólico da linguagem. (Ullmann, 1964:338)

(iv) Homônimos reinterpretados, ou seja, "quando duas palavras têm som idêntico e a diferença de significado não é muito grande, temos uma certa tendência a considerá-las como uma única palavra com dois sentidos" (Ullmann, 1964:340). Segundo o autor, essas duas palavras seriam homônimas, já que suas origens seriam diferentes, mas os falantes desconheceriam tal fato e seriam capazes de estabelecer relações de significado entre elas. Casos como esses são raros e imprecisos;

(v) Influência estrangeira, em que há a mudança de sentido de uma palavra já existente num sistema lingüístico por "importação de significado" de uma palavra estrangeira. Tende-se à co-existência dos dois significados: o novo e o antigo, dando origem à polissemia. Segundo Ullmann (1964), "o empréstimo semântico, apesar de muito comum em certas situações, não é um processo normal na linguagem quotidiana" (p.346).

A polissemia é um fenômeno que está naturalmente presente em uma língua natural; é um fator de economia e de flexibilidade para a eficiência desse mesmo sistema lingüístico. Não importa quantos significados tenha um dado item lexical: dada a influência do contexto, não haverá confusão entre eles, se a um certo significado for dado um determinado sentido somente numa situação precisa. A frequiência de uma palavra está relacionada com a sua polissemia. Com efeito, "quanto mais freqüente é uma palavra mais

3 O autor refere-se a termos ou unidades léxicas especializadas, que devem ser tratados e estudados no âmbito da Terminologia. 
sentidos é possível que tenha" (Ullmann 1964:350).

No que diz respeito à polissemia, Biderman (1991) a trata como sendo

um fenômeno que ocorre no interior das redes de significação do léxico geral da língua comum, em virtude da economia lingüística, com o reaproveitamento freqüente de um certo número de lexemas no processo de comunicação. A ampliação do uso de uma palavra e a metaforização contínua da linguagem acarretam a freqüência de muitas unidades lexicais gerando a polissemia. (Biderman 1991:283-284)

Essa mesma autora também estabelece relação entre o uso frequiente das palavras e o fenômeno da polissemia. De fato, palavras que possuem alta frequiência são polissêmicas.

Para Barbosa (1996:245-249), um significado polissêmico é quando num mesmo significante unem-se vários feixes de semas ou sememas, que se diversificam pelas combinações diferentes de semas. Dessa forma, uma lexia polissêmica é aquela que preserva uma unidade de significado, isto é, a sua unidade é garantida pelo núcleo sêmico comum aos múltiplos setores de semas. Com efeito, esse núcleo sêmico comum é que permite ao falante identificar um único signo lingüístico em suas diferentes realizações no discurso.

Para Rehfeldt (1980), "polissemia (...) segundo os próprios componentes (poly + sema + ia), é palavra que comporta várias significações” (p.77). Essa autora diz que a arbitrariedade lingüística é uma das causas da polissemia e que o reaproveitamento de uma mesma unidade lingüística pode ser visto como uma deficiência desse sistema lingüístico, uma vez que não é consenso que a polissemia seja entendida como economia lingüística.

Em contrapartida, Bréal ${ }^{4}$ (1992) faz relatos sobre a superioridade de uma língua que abarca novas significações para uma palavra já existente, sem, contudo, perder de vista o seu significado antigo e primário. De fato, os novos significados coexistirão, lado a lado, com o antigo. Nesse sentido, Bréal (1992) diz:

À medida que uma significação nova é dada à palavra, parece multiplicar-se e produzir exemplares novos, semelhantes na forma, mas diferentes no valor. A esse fenômeno de multiplicação chamaremos a polissemia. Todas as línguas das nações civilizadas participam desse fenômeno; quanto mais um termo acumulou significações, mais se deve supor que ele represente aspectos diversos da atividade intelectual e social. (Bréal, 1992:103)

Esse mesmo autor atenta para o fato de os diversos sentidos não se mis- 
turarem ou se contradizerem, uma vez que são inseridos cada qual em um contexto que precisa e antecipa a sua carga semântica. Assim sendo, um significado só terá sentido em uma determinada situação, dado que os outros significados não existirão (e não se confundirão) na mente do interlocutor. Com efeito, trata-se de um signo que possui um significante e um significado que é empregado em uma pluralidade de sentidos mais ou menos ampla; a correlação existente entre os diversos sentidos conduzem a um mesmo significante (fato esse que diferencia a polissemia da homonímia). Para tanto, podemos traçar o seguinte esquema:

\section{Significante}

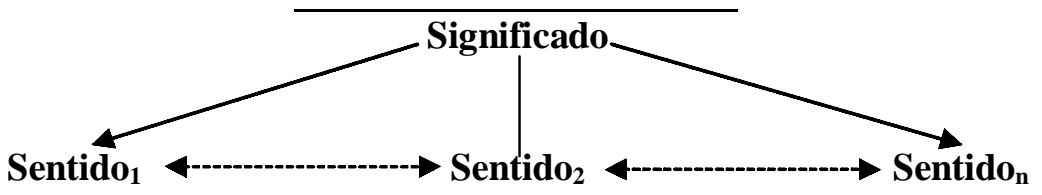

\section{Homonímia}

Ullmann (1964:364-374) diz que apesar de a homonímia ser muito menos comum e complexa do que a polissemia, seus efeitos podem ser tão graves quanto ou até mesmo mais contundentes. Segundo ele, existem somente três processos pelo qual a homonímia pode surgir:

(i) Convergência fonética, ou seja, o desenvolvimento de sons convergentes, isto é, quando dois ou mais itens lexicais tiveram, no passado, formas diferentes que coincidem na linguagem falada e escrita;

(ii) Divergência semântica, ou seja, quando há o desenvolvimento de sentidos divergentes, isto é, "quando dois ou mais significados da mesma palavra se separam de tal modo que não haja nenhuma conexão evidente entre eles, a polissemia dará lugar à homonímia e a unidade da palavra será destruída (...)" (Ullmann, 1964:368). É o caso de palavras como canal1 (abertura, passagem de água, cavidade) e canal2 (meio de transmissão de sinais); criação1 (obra, invenção) e criação2 (animais domésticos criados conjuntamente), dentre muitos outros exemplos do português contemporâneo;

(iii) Influência estrangeira, ou seja, quando palavras estrangeiras se introduzem em uma língua, adaptando-se ao sistema fonético no qual se introduziram, e coincidem com outras palavras já existentes; conseqüentemente, surgem pares de homônimos. Segundo Ulmann (1964), além de ser um processo raro, "este tipo de influência estrangeira não é, pois, 
uma fonte separada de homonímia, mas apenas uma forma especial de desenvolvimentos fonéticos convergentes" (p.373).

Baldinger (1970:42-43) relaciona os estudos de Saussure, relativos à diacronia e à sincronia, aos estudos da homonímia e polissemia. Segundo ele, diacronicamente falamos de homonímia se as palavras coincidem foneticamente na sua evolução histórica e se coincidem na estrutura fonológica; sincronicamente, a homonímia é uma polissemia, ou seja, uma forma léxica com dois significados. Temos, portanto, que no plano da sincronia, duas formas léxicas podem ser percebidas como uma forma léxica com dois significados:

forma léxica ${ }_{I}$

y

$\lambda$

forma léxica 2
$\Rightarrow \quad$ significado $_{I}$

$\Rightarrow$ polissemia

$\Rightarrow \quad$ significado $_{2}$

E temos também uma forma léxica com dois significados que pode se realizar como duas formas léxicas:

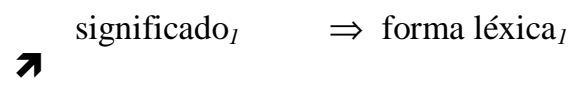

forma léxica

$$
\Rightarrow \text { homonímia }
$$

significado $_{2} \quad \Rightarrow$ forma léxica $_{2}$

Esse autor conclui dizendo que a homonímia pode chegar a ser polissemia, e a chama de Polissemia Homonímica.

Lyons (1977) questiona-se sobre o fato de dicionários ingleses atribuírem, geralmente, duas entradas para a lexia inglesa found, uma significando "estabelecer" e outra "fundir e deitar num molde". Deduz que, se assim o fizeram, é porque a consideraram como dois lexemas distintos: foundl e found2, e que tal determinação pode ter surgido das diferentes origens etimológicas para cada um dos significados de found. Postula que a diferenciação com base na semântica das palavras seja importante e, assim, presume que a lexia found se tenha cindido em duas "com base no fato de os seus significados não só serem diferentes, como estranhos, um ao outro” (Lyons, 1977:27). Para ele, homônimas são palavras, isto é, lexemas que possuem a mesma forma, diferindo nos seus significados. Ressalva, porém, que "os lexemas, enquanto tal, são entidades abstratas e não têm uma forma. Estão associados a um conjunto de uma ou mais formas. Por conseguinte, é neste 
sentido que devemos compreender a habitual definição de homonímia: os homônimos são lexemas em que todas as formas têm a mesma forma" (Lyons, 1977:27).

Berruto (1979:93) diz que a noção de homonímia traz alguns problemas e se pergunta como estabelecer quais significados de um mesmo significante são realmente distintos entre si. Estabelece tal distinção sob dois pontos de vista: no primeiro, tem-se duas palavras distintas quando pertencem a classes gramaticais diferentes, como por exemplo, atraso (substantivo) e atraso (verbo) e, no segundo, tem-se a distinção etimológica, ou seja, diacronicamente, uma mesma forma com duas origens diferentes, como em [pena $<$ penna $=$ "de ave"] e [pena < poena = "castigo, punição"].

Segundo esse autor, a homonímia deveria se diferenciar segundo a realização oral (fônica) e escrita (gráfica) dos significantes, ou seja, entre homofonia (sons iguais) e homografia (grafia igual). Dessa maneira, haveria lexias que poderiam ser:

a) homófonas e homógrafas ao mesmo tempo, como no português canto (substantivo) X canto (verbo);

b) lexias que poderiam ser homógrafas mas não homófonas, pois difeririam na sua realização oral, como por exemplo, para o português apelo (substantivo) e apelo (verbo) em que a categoria do substantivo realiza-se fonicamente como [e] e a do verbo como [e] e a do verbo como $[\varepsilon] \mathrm{e}$

c) lexias que poderiam ser homófonas mas não homógrafas como no português sexta e cesta.

Segundo Biderman (1978:128): "homônimos são palavras que têm formas idênticas, mas que expressam conteúdos distintos. Em outras palavras: significantes idênticos se referem a significados diferentes". Para ela, existem três tipos de itens homônimos, a saber:

(i) homônimos léxicos, ou seja, aqueles que se incluem em uma classe sintática e possuem significados diferentes: canto1 (s.m. - ângulo, esquina, lugar retirado) X canto2 (s.m. - som musical, música vocal);

(ii) homônimos sintáticos, i.e, aqueles que pertencem a classes sintáticas diferentes: canto1 (s.m. - ângulo, esquina, lugar retirado) X canto3 (1a pessoa singular do Presente Indicativo do verbo cantar);

(iii) homônimos morfológicos, ou seja, aqueles que pertencem à mesma classe sintática e se referem a categorias gramaticais diversas: nós amamos1 V. (Presente Indicativo) X nós amamos2 V. (Pretérito Perfeito). 
Para Silva (1989), a homonímia

consiste em que um mesmo significante pode significar simultaneamente dois ou mais significados entre os quais não existe qualquer relação cognitiva. Neste caso, não pode falar-se de uma palavra com vários significados, mas de várias palavras (homônimas) com o mesmo significante. (Silva, 1989:1)

Esse autor oferece uma importante contribuição aos estudos da homonímia (e também da polissemia) para a língua portuguesa. De base empírica, sua pesquisa buscou distinguir palavras homônimas de polissêmicas, por meio de testes feitos com falantes do português, baseando-se em graus de similaridade, numa escala de 0 a 4 . Esses valores foram atribuídos a pares de palavras por falantes do português. Seus resultados demonstraram que houve um elevado consenso, por parte dos falantes, na demarcação das fronteiras entre os dois fenômenos e que, conseqüentemente, a homonímia e a polissemia encontravam-se bastante distintas na mente dos informantes, fato esse que nos leva a inferir que os falantes seriam dotados de mecanismos desambiguadores subjacentes à sua própria compreensão.

Segundo Saba (1998:2), “a homografia é aquele fenômeno lingüístico no qual formas graficamente idênticas têm funções e significados distintos". Para a autora, as formas graficamente idênticas podem se realizar em todas as categorias gramaticais, podendo se referir às palavras lexicais. Além disso, as formas homógrafas podem possuir categorias gramaticais "múltiplas" (verbo/substantivo/adjetivo/advérbio). A homografia pode gerar ambigüidades do tipo léxica, funcional e gramatical:

(i) a ambigüidade léxica refere-se a palavras que são semanticamente diferentes;

(ii) a ambigüidade funcional é relativa às diferentes funções que uma mesma forma pode possuir, como por exemplo, morto que pode ser particípio passado, adjetivo e substantivo;

(iii) a ambigüidade gramatical se refere às homografias internas ao lema, isto é, quando duas ou mais formas têm a mesma função e mesmo significado, mas são diferentes em gênero e número, como por exemplo a forma nominal formidável que é masculino singular e feminino singular ao mesmo tempo. Um outro exemplo é quando essas formas têm diferentes modos, tempos ou pessoas quando se trata de verbos: venha (1a e $3 \mathrm{a}$ pessoa do Presente do Subjuntivo e 3 a pessoa singular do Imperativo Afirmativo).

Em suma, no que concerne a homonímia, os significados que são expressos por um mesmo significante são totalmente estranhos um ao outro. Dito isso, 
sugerimos o seguinte esquema para representarmos esse fenômeno:

\begin{tabular}{lllll} 
Significante & Significante & $=$ & Significante \\
\hline Significado $_{1}$ & $\neq$ & Significado $_{2}$ & $\neq$ & Significado $_{\mathrm{n}}$
\end{tabular}

Das pesquisas teóricas realizadas, constatamos que a homonímia, enquanto fenômeno de uma língua natural, não é mais intrigante e enigmática do que a sua própria definição, ou seja, a sua compreensão e a sua delimitação. Para defini-la, os autores oscilam entre critérios diacrônicos, convergência fonética, divergência semântica, influência estrangeira, polissemia homonímica, critérios sintáticos e morfológicos, distinções estilísticas e sociais, ortografia, entre outros, como demonstrado anteriormente.

Por conseguinte, com o propósito de oferecermos uma conceitualização uniforme desses fenômenos, legitimamos os seguintes postulados teóricos:

(I) A homonímia é o fenômeno lingüístico em que se tem a identidade de duas lexias no plano da expressão, ou seja, formas perfeitamente iguais que se distinguem semanticamente (um significante para dois significados, no plano do conteúdo) ou a identidade de duas construções gramaticais, gerando a ambigüidade. O primeiro refere-se à homonímia lexical e o segundo à homonímia estrutural.

(II) Para a homonímia lexical, a igualdade de formas pode se realizar tanto graficamente como fonicamente. No primeiro caso, as lexias possuem identidade de grafia (homografia) e no segundo, identidade de som (homofonia). E assim, temos lexias homógrafas que:

(a) são distintas quanto ao seu significado e idênticas, tanto oralmente como gramaticalmente, caso esse denominado de Homonímia Semântica; como:

banco $_{1}$ : "objeto feito para sentar" X banco $_{2}$ : "lugar em que se deposita dinheiro"

ponto $_{1}$ : "porção do espaço designada com precisão" $X$ ponto $_{2}$ : "grau determinado numa escala de valores" $X$ ponto $_{3}$ : "cada parte de um discurso, texto, de uma lista de assuntos de um programa" $X$ ponto 4 : "cada extensão do fio de linha entre dois furos feitos por uma agulha|";

importar $_{1}$ : "trazer algo de outro país" X importar $_{2}$ :"ser necessário, valer" 
b) são distintas quanto ao fato de pertencerem a classes gramaticais diversas e serem idênticas oralmente caso esse denominado de Homonímia Categorial, como:

$\boldsymbol{a b a n d o n o}_{1}$ (substantivo) X abandono $_{2}$ (verbo) ameaça $_{1}$ (substantivo) X ameaça $_{2}$ (verbo)

(c) são distintas quanto ao seu étimo e idênticas oral e graficamente, caso esse denominado de Homonímia Etimológica, como:

$\boldsymbol{m a n g a}_{1}$ : "fruto" [Do malaiala manga.] X $\boldsymbol{m a n g a}_{2}$ : "parte do vestuário" [Do lat. manica, 'manga de túnica'.]

(d) são distintas na sua realização oral, caso esse denominado de Homonímia Heterófona ${ }^{6}$, nas quais o substantivo realiza-se fonicamente como [e] ou [o] e o verbo como [E] ou [ 0 ] como nos seguintes exemplos:

\begin{tabular}{|l|} 
apelo $_{1}$ (substantivo) $X$ apelo $_{2}$ (verbo) \\
aperto $_{1}$ (substantivo) X aperto $_{2}$ (verbo) \\
gosto $_{1}$ (substantivo) $X$ gosto $_{2}$ (verbo) \\
choro $_{1}$ (substantivo) $X$ choro chorbo $_{2}$ (verbo \\
\hline
\end{tabular}

(III) As lexias homófonas são aquelas distintas na grafia e idênticas no som, como por exemplo:

sensor: "dispositivo" X censor : "crítico"

cessão: "ato de ceder" X seção: "segmento, divisão" X sessãa: "espaço de tempo que dura uma reunião, um ato"

(IV) Já a homonímia estrutural realiza-se quando temos duas construções gramaticais idênticas com sentidos diferentes:

Falei com o rapaz de maî́ (falei com o rapaz que usava maiô) X Falei com o rapaz de maiô (falei com o rapaz enquanto eu usava maiô).

\section{Homonímia versus polissemia: critérios distintivos}

Lyons (1987:142) diz que, a princípio, a diferença entre homonímia e polissemia está na afirmação de que "a polissemia (ou significado múltiplo) é uma propriedade de lexemas simples”. Ele diz:

6 Forma que possui grafia idêntica a de uma outra forma e ambas se pronunciam diferentemente. 
Por exemplo, 'bankl' [margem de rio] e 'bank2' [instituição financeira] são normalmente tidos como homônimos, ao passo que 'neck' [pescoço, gargalo] é normalmente tratado pelos dicionários do inglês como um único lexema com diferentes significados: ou seja, como polissêmico. Nosso sistema de notação pode captar a distinção entre homonímia e polissemia; haja vista 'bankl' e 'bank2' , cada um podendo na realidade ser polissêmico; mas 'neck', cujos significados são, grosso modo, 'neckl' = "parte do corpo", 'neck2' = "parte da camisa ou vestimenta" [gola], 'neck3' = "parte da garrafa”, 'neck4' = "faixa estreita de terra” [restinga], etc. [sic]. (Lyons 1987:142)

Para esse autor, um dos critérios de distinção entre esses dois fenômenos é o critério etimológico, uma vez que seria uma condição para a classificação de formas léxicas como homônimas. Entretanto, para a lingüística sincrônica, esse critério é irrelevante: mesmo que duas palavras estejam relacionadas historicamente quanto aos seus significados, sincronicamente o usuário não estabelece relação entre elas, dado que seus significados divergiram de tal maneira a ponto de pensar-se tratar de duas formas completamente diferentes e que nunca estiveram relacionadas antes. Por outro lado, considera importante a relação entre significados de um item lexical como critério distintivo: os vários significados de um item polissêmico estão relacionados entre si, ao passo que se não houver nenhuma relação entre significados, o item lexical deve ser considerado homônimo. Ele acrescenta, todavia, que esse critério é difícil de ser aplicado com segurança e coerência. E afirma:

A única forma de resolver, ou talvez de delimitar, o problema tradicional da homonímia e polissemia é abandonar totalmente os critérios semânticos, na definição do lexema, contando apenas com os critérios sintáticos e morfológicos. O efeito desta resolução seria transformar "bankl" e "bank2" em dois significados (prontamente distinguíveis) de um mesmo lexema sincronicamente polissêmico. A maior parte dos lingüistas não estaria a favor de uma solução assim tão radical. Entretanto ela é teórica e praticamente mais sustentável do que sua alternativa. Talvez devêssemos nos contentar com o fato de que o problema da distinção entre homonímia e polissemia seja, em princípio, insolúvel. (Lyons 1987:143)

Essa afirmação de Lyons é discutível, na medida em que, não podemos e não devemos renunciar os critérios semânticos para a distinção de itens homônimos de polissêmicos, ao menos em uma visão sincrônica da língua. Com efeito, critérios puramente sintáticos e morfológicos dão conta de distinguir apenas uma parte dos itens homônimos dos polissêmicos. Mais adiante estaremos expondo, justamente, critérios semânticos para a demarcação entre esses dois fenômenos. 
Sandmann (1990) enuncia que a homonímia e a polissemia contestam o desiderato, usando a mesma expressão do autor, de univocidade de cada signo lingüístico em confronto a outros signos, isto é, de que "a cada significante corresponda apenas um significado, em outros termos, que cada sinal físico transmita um só conceito, idéia ou mensagem” (p.1). Para esse autor:

a polissemia é a figura em que a um significante correspondem significados aparentados (dois ou mais) - estamos diante de uma unidade lexical apenas, mas com diferentes acepções - enquanto a homonímia é a figura em que a um significante correspondem significados diversos (dois ou mais) - estamos diante de duas ou mais unidades lexicais diferentes. (Sandmann 1990:2)

Sandmann (1990) aponta três critérios para a distinção desses dois fenômenos lingüísticos: (i) o critério etimológico, já visto anteriormente; (ii) o critério semântico, que segundo o autor, é problemático na medida em que torna-se difícil de se estabelecer a linha limítrofe entre dois conceitos, ou ainda, o grau de diferença entre eles para estarmos diante da homonímia ou da polissemia e (iii) o critério formal, ou seja, a distribuição na frase: se uma unidade lexical puder ser classificada em diferentes classes de palavras, estaremos diante da homonímia; por sua vez, se a unidade lexical preencher somente uma mesma classe de palavras, será classificada como polissêmica.

Segundo Câmara Jr. (1985), o critério mais adequado para se distinguir a homonímia da polissemia é o critério da distribuição das formas. Com isso, uma mesma distribuição de formas em uma frase é sinal de polissemia, ao passo que uma distribuição diferente revela homonímia:

Nos exemplos portugueses que estamos trazendo à baila, cabo, com seus 3 sentidos é uma forma polissêmica, pois a sua distribuição, como substantivo, é a mesma na sentença (como sujeito, como objeto e assim por diante). Já canto, substantivo, e canto, forma verbal, são homônimos, uma vez que nos padrões das sentenças se distribuem de maneira diversa (um canto alegre / canto alegremente etc.). (Câmara Jr. 1985:28)

Esse critério distintivo de Câmara Jr, (como ocorreu com Lyons anteriormente) em que prevalece um ponto de vista morfossintático, também é contestável na medida em que o autor não considera casos de Homonímia Semântica, cuja distribuição de formas é a mesma. Com efeito, consideramos cabo como sendo uma forma homônima e não polissêmica, numa visão sincrônica.

Por sua vez, Pottier (1968) distingue os dois fenômenos com base na semântica das palavras, máxime para a coincidência ou não de semas: os casos de homonímia abarcam sememas completamente disjuntos, isto é, 
independentes um do outro, em que não há coincidência de nenhum sema (manga "fruta" X manga "parte do vestuário"); já os casos de polissemia abrangem formas em que pelo menos um sema ocorre em oposição significativa, isto é, existe uma intersecção de traços significativos entre as formas (capa de livro x capa de chuva).

Werner (1982:297-314) estabelece alguns critérios para que se mantenha a distinção entre a homonímia e a polissemia. Destacamos dois deles:

(i) Critério da etimologia, pelo qual existe a polissemia quando distintos conteúdos correspondem a significantes iguais, desde que, de um ponto de vista diacrônico, tenham uma origem idêntica (resultado de uma divergência diacrônica no plano do conteúdo); ao contrário, existe a homonímia quando a dois conteúdos diferentes correspondem significantes iguais, desde que, diacronicamente, originem-se de diferentes significantes (resultado de uma convergência diacrônica no plano da expressão). Para a descrição sincrônica de línguas, esse critério pode tornar-se inadequado, na medida em que pode ser impossível de se reconstruir a sua evolução diacrônica.

(ii) Critério da consciência lingüística dos usuários, pelo qual existe a polissemia quando na consciência do falante há uma relação entre os diferentes conteúdos que podem corresponder a somente uma forma no plano da expressão. Inversamente, existe a homonímia quando o falante não estabelece nenhuma relação entre os diferentes conteúdos de uma única forma no plano da expressão. Segundo o autor, esse critério é bastante contestável, para uma distinção científica entre a homonímia e a polissemia, uma vez que existe uma arbitrariedade sobre o que o falante de uma língua pode ou não estabelecer como relação (ou não) de uma determinada unidade lingüística. Dessa forma, ele propõe, segundo a teoria da semântica estrutural, a identificação de elementos comuns de sememas ${ }^{7}$ para os casos de identidade no plano da expressão e, diversamente, a divergência no plano do conteúdo. Assim, haveria polissemia quando, no plano da expressão, a uma única forma corresponderiam vários sememas que possuíssem pelo menos um sema em comum; em contrapartida, haveria homonímia quando esses sememas não possuíssem nenhum sema em comum.

Silva (1989) também propôs a análise sêmica como critério teórico de distinção para itens homônimos de polissêmicos. Para tanto, salientou a importância da distinção de semas genéricos e semas específicos bem como

\footnotetext{
"Na terminologia da análise sêmica*, o semema é a unidade que tem por correspondente formal o lexema; ele é composto de um feixe de traços semânticos chamados semas (unidades mínimas nãosusceptíveis de realização independente). O semema de cadeira comporta os semas S1, S2, S3, S4 ("com encosto", "sobre pernas", "para uma só pessoa", "para sentar-se"; observa-se que a adjunção de um sema S5 ("com braços") realiza o semema de poltrona" (Dubois 1973:534).
} 
de "relacionamentos triviais" e "relacionamentos não-triviais". Por exemplo, para o autor não se justifica que os semas "objeto físico", "concreto", "inanimado" caracterizem como polissêmicas lexias como banco1 (assento) e banco2 (estabelecimento), dado à sua natureza claramente genérica. Da mesma forma, "dizer que em vela (de barco) e vela (objeto de cera) há polissemia, justificada pelo conteúdo 'orientação', é insustentável porque se trata de uma associação subjetiva e trivial” (Silva, 1989:6).

Para ele, então, a distinção entre a polissemia e a homonímia dar-se-á dependendo da existência ou não de semas específicos comuns (pelo menos um).

Com o escopo de corroborarmos com esse critério distintivo, vejamos a sua aplicação em algumas formas homônimas do português vertente brasileira, extraídas de Biderman (1998):

\begin{tabular}{|c|c|c|c|c|c|}
\hline \multicolumn{3}{|c|}{ ITENS HOMÔNIMOS } & \multicolumn{3}{|c|}{ Análise sêmica } \\
\hline \multicolumn{2}{|c|}{$\begin{array}{l}\text { banco, }_{1} \text { Objeto com ou } \\
\text { sem encosto no qual as } \\
\text { pessoas se sentam, de } \\
\text { várias formas, tamanhos } \\
\text { e material. }\end{array}$} & $\begin{array}{lr}\text { banco: }: & \text { Instituição } \\
\text { financeira } & \text { cuja } \\
\text { finalidade é } & \text { operar com } \\
\text { dinheiro, títulos, e outros } \\
\text { valores. }\end{array}$ & \multicolumn{2}{|c|}{$\begin{array}{l}\text { banco: }: \\
\text { [+objeto físico] } \\
\text { [+concreto] } \\
{[+ \text { inanimado] }} \\
\text { [+duro] }\end{array}$} & $\begin{array}{l}\text { banco } 2: \\
\text { [+espaço físico] } \\
\text { [+concreto] } \\
\text { [+inanimado] }\end{array}$ \\
\hline \multicolumn{2}{|c|}{ 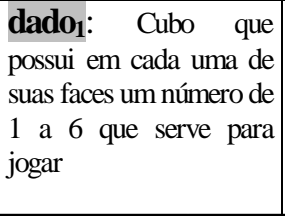 } & 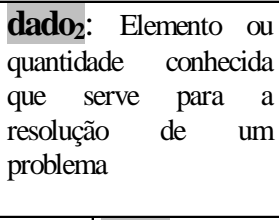 & \multicolumn{2}{|c|}{$\begin{array}{l}\text { dado: }: \\
\text { [+concreto] } \\
\text { [+objeto físico] } \\
\text { [+inanimado] } \\
\text { [+jogar] } \\
\text { [+duro] }\end{array}$} & $\begin{array}{l}\text { dado: } \\
\text { [+abstrato] } \\
\text { [-concreto] } \\
\text { [+inanimado] } \\
\text { [+quantidade] } \\
\text { [+informação] }\end{array}$ \\
\hline $\begin{array}{l}\text { guia }_{1} \text { : Pessoa } \\
\text { que orienta ou } \\
\text { acompanha } \\
\text { alguém }\end{array}$ & $\begin{array}{l}\text { guia2: } \\
\text { que } \\
\text { informaç } \\
\text { turísticas } \\
\text { um lug } \\
\text { dados ge } \\
\text { um } \\
\text { determin } \\
\text { assunto }\end{array}$ & \begin{tabular}{r|l}
\multicolumn{1}{r|}{ Livro } & guia3: \\
contém & Formulário que \\
ções & serve para \\
s sobre & solicitar algo \\
gar ou & \\
serais de & \\
nado & \\
nado &
\end{tabular} & $\begin{array}{l}\text { guia } 1 \\
\text { [+humano] } \\
\text { [+concreto] } \\
\text { [+animado] }\end{array}$ & \begin{tabular}{|l} 
guia2: \\
[+objeto \\
físico] \\
[+concreto] \\
[+inanimado] \\
[+duro]
\end{tabular} & $\begin{array}{l}\text { guia3: } \\
\text { [+objeto físico] } \\
\text { [+concreto] } \\
\text { [+inanimado] } \\
\text { [+solicitação] }\end{array}$ \\
\hline \multicolumn{2}{|c|}{$\begin{array}{l}\text { heroína: Mulher que } \\
\text { possui muita coragem e } \\
\text { pratica atos notáveis }\end{array}$} & $\begin{array}{l}\text { heroína2: } \quad \text { Droga } \\
\text { perigosa que vicia quem } \\
\text { a usa }\end{array}$ & \multicolumn{2}{|l|}{$\begin{array}{l}\text { heroína } 1 \\
\text { [+humano] } \\
\text { [+concreto] } \\
\text { [+animado] } \\
\text { [+coragem] } \\
\text { [+fêmea] }\end{array}$} & $\begin{array}{l}\text { heroína: } \\
\text { [+concreto] } \\
\text { [+inanimado] } \\
\text { [+pó] } \\
\text { [+substância] } \\
\text { [+contável] }\end{array}$ \\
\hline \multicolumn{2}{|c|}{$\begin{array}{l}\text { renda1: Quantia em } \\
\text { dinheiro que se recebe } \\
\text { como retribuição de } \\
\text { trabalho ou capital } \\
\text { aplicado. }\end{array}$} & $\begin{array}{ll}\text { renda2: } & \text { Tecido } \\
\text { delicado cujos fios se } \\
\text { entrelaçam e formam } \\
\text { desenhos variados. }\end{array}$ & $\begin{array}{l}\text { renda }: \\
\text { [+abstrato] } \\
\text { [+inanimado] } \\
\text { [+contável] }\end{array}$ & \multicolumn{2}{|c|}{$\begin{array}{l}\text { renda2: } \\
\text { [+concreto] } \\
\text { [+inanimado] } \\
\text { [+material] } \\
\text { [+seda]/[+algodão] }\end{array}$} \\
\hline
\end{tabular}




\begin{tabular}{|c|c|c|c|}
\hline $\begin{array}{l}\text { soda1: } \\
\text { branca e corrosiva em em } \\
\text { pedaços ou em pó usada } \\
\text { emindústrias }\end{array}$ & \begin{tabular}{|l} 
soda2: Bebida não \\
alcoólica, com gás
\end{tabular} & \begin{tabular}{|l|} 
Sodaa: \\
[+concreto] \\
[+inanimado] \\
[+contável] \\
[+substância] \\
[+branca] \\
[+corrosiva] \\
[+pó]
\end{tabular} & \begin{tabular}{|l} 
Soda: \\
[+concreto] \\
[+inanimado] \\
[+contável] \\
[+líquido] \\
[+transparente]
\end{tabular} \\
\hline $\begin{array}{l}\text { vale: } \\
\text { depressão de terra entre } \\
\text { montanhas ou quaisquer } \\
\text { outras superfícies }\end{array}$ & $\begin{array}{l}\text { vale: Documento em } \\
\text { papel que equivale a } \\
\text { dinheiro, } \\
\text { formalidade legal }\end{array}$ & \begin{tabular}{|l|} 
vale $:$ \\
[+concreto] \\
[+inanimado] \\
[+espaço \\
físico] \\
[+profundida \\
de]
\end{tabular} & $\begin{array}{l}\text { vale: } \\
\text { [+concreto] } \\
\text { [+inanimado] } \\
\text { [+papel] } \\
\text { [+contável] }\end{array}$ \\
\hline
\end{tabular}

Tabela 1 - Itens homônimos - Análise sêmica

Para Silva (1989), outro método distintivo para esses dois fenômenos é o campo léxico. Para isso, é necessário que se distingam diversas situações:

1. os significados pertencem a campos léxicos totalmente diferentes, sem qualquer conteúdo sémico ou arquissémico comum: homonímia; 2 os significados pertencem ao mesmo campo léxico (centro ou periferia): polissemia; 3. os significados pertencem, de jure, a campos léxicos em relação de inclusão ou de afinidade, ou a campos léxicos com conteúdo sémico ou arquissémico comum (intersecção de campos): polissemia; 4. transferência de significado de uma unidade (ou mais) de um campo léxico, para outro, isto é, uma ou mais unidades do centro ou da periferia de determinado campo léxico transferem o seu significado desse campo léxico para outro: polissemia; 5. neutralização de campos léxicos. (Silva 1989:6-7)

Silva (1989:7) salienta que existe uma certa dificuldade em se delimitar campos léxicos, e que, devido a esse fato, esse método de distinção parece não ser conveniente nem convincente. Ademais, nem todas as palavras parecem pertencer a campos léxicos. Por conseguinte, vem à tona o conceito de campo semântico no qual existe uma área de significação comum, em que existem relações entre várias unidades léxicas que podem ou não formar campos léxicos. O autor apresenta resultados apropriados para a aplicação dos critérios teóricos propostos, por meio de exemplos das análises de pares de palavras homônimas e polissêmicas.

Nessa mesma direção, Biderman (1991) atenta para o fato de que palavras homônimas podem permitir a derivação de vocábulos diferentes: 
saber: temos em português duas unidades lexicais distintas: bancol "objeto alongado, com ou sem encosto, que serve para assentar" e banco 2 "empresa financeira, que opera com dinheiro, títulos e outros valores". Esse consenso é corroborado pelo fato (lembrado por Sandman) de que bancol gera vocábulos diferentes (bancada, banqueta) de banco2 (bancário, banqueiro, bancar). (Biderman, 1991:288)

A esse propósito, perfilam-se dois conceitos que convém salientarmos, a saber: o de campos lexicais/léxicos e o de campos semânticos. Dessa maneira, Campo Lexical é o conjunto das unidades lexicais que se assemelham e de uma noção, de um objeto, etc. Em contrapartida, Campo Semântico é o conjunto das unidades lexicais enquanto conteúdo e significado, que adquirem uma carga semântica específica por meio da sua contextualização. Em conformidade, Rehfeldt (1980) propõe a seguinte distinção para essas duas noções:

O campo lexical é composto de lexemas (ou signos, vocábulos, palavras) relacionados entre si por semelhança de: contigüidade, sinonímia, no nível, portanto, de lexema. O campo semântico é constituído de sememas. Cada semema representa uma possibilidade de atualização do lexema. Assim, um lexema pode englobar vários sememas. (Rehfeldt 1980:95)

Como o propósito de fortificarmos o critério distintivo do campo léxico para os fenômenos da homonímia e da polissemia sugerido por Silva (1989) e Biderman (1991), o aplicamos em alguns homônimos do português do Brasil. Vejamos os resultados:

\begin{tabular}{|c|c|c|c|}
\hline \multicolumn{2}{|c|}{ ITENS HOMÔNIMOS } & \multicolumn{2}{|c|}{ CAMPO LÉXICO } \\
\hline $\begin{array}{lr}\text { banco }_{1} \text { : } & \text { Objeto } \\
\text { com ou } & \text { sem } \\
\text { encosto no } & \text { qual as } \\
\text { pessoas se } & \text { sentam, } \\
\text { de várias } & \text { formas, } \\
\text { tamanhos } & \text { e } \\
\text { material. } & \end{array}$ & $\begin{array}{llr}\text { banco }_{2} \text { : } & \text { Instituição } \\
\text { financeira } & \text { cuja } \\
\text { finalidade } & \text { é operar } \\
\text { com } & \text { dinheiro, } \\
\text { títulos, e r outros } \\
\text { valores. }\end{array}$ & $\begin{array}{l}\text { banco: } \\
\text { banquinho; } \\
\text { bancaria; } \\
\text { bancada; } \\
\text { banqueta }\end{array}$ & $\begin{array}{l}\text { banco }_{2} \text { : } \\
\text { banqueiro; bancário; } \\
\text { bancar }\end{array}$ \\
\hline $\begin{array}{l}\text { cálculo: Operação } \\
\text { com números ou } \\
\text { outros símbolos }\end{array}$ & $\begin{array}{|lrr|}\text { cálculo }: & \text { (Méd.) } \\
\text { Solidificação } & \text { que } \\
\text { se forma na bexiga, } \\
\text { no rim } & \text { ou } & \text { na } \\
\text { vesícula, } & \text { mais } \\
\text { conhecida } & \text { como } \\
\text { pedra, provocando } \\
\text { dores } & & \text { e } \\
\text { complicações } & \text { para } \\
\text { a saúde } & \text { de } & \text { uma } \\
\text { pessoa } & & \\
\end{array}$ & $\begin{array}{l}\text { cálculo1: } \\
\text { calculista; } \\
\text { calculador; } \\
\text { calculadora }\end{array}$ & cálculo 2 : calculose \\
\hline
\end{tabular}




\begin{tabular}{|c|c|c|c|c|c|}
\hline $\begin{array}{l}\text { canto }_{1 \mathrm{a}}: \text { Som } \\
\text { musical formado } \\
\text { pelo conjunto de } \\
\text { várias vozes }\end{array}$ & \begin{tabular}{l|} 
canto $_{2 \mathrm{a}}:$ Angulo \\
que se forma \\
quando duas \\
paredes (ou \\
qualquer outra \\
coisa) se encontram
\end{tabular} & \begin{tabular}{|l|} 
canto $_{1 \mathrm{a}}:$ \\
cantochão; \\
canto-de- \\
passarinho; \\
canto-de-sabiá
\end{tabular} & \multicolumn{3}{|c|}{$\begin{array}{l}\text { canto }_{2 \mathrm{a}}: \\
\text { cantoneira }\end{array}$} \\
\hline $\begin{array}{l}\text { jardim } 1 \text { Lugar no } \\
\text { qual se cultivam ou } \\
\text { se plantam flores } \\
\text { e/ou árvores } \\
\text { ornamentais }\end{array}$ & $\begin{array}{l}\text { jardim }_{2}: \quad \text { Escola } \\
\text { para crianças de até } \\
\text { seis anos de idade }\end{array}$ & $\begin{array}{l}\text { jardim } ; \\
\text { jardinagem; } \\
\text { ajardinar; } \\
\text { jardineira; } \\
\text { jardineiro; } \\
\text { jardim-de-- } \\
\text { inverno; jardim } \\
\text { botânico } \\
\end{array}$ & \multicolumn{3}{|c|}{$\begin{array}{l}\text { jardim }_{2} \text { : } \\
\text { jardim-de-infância; } \\
\text { jardim infantil }\end{array}$} \\
\hline 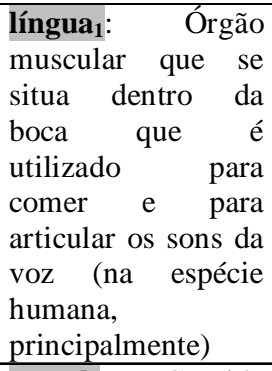 & $\begin{array}{lr}\text { língua } 2 \text { : Conjunto } \\
\text { ou sistema de } \\
\text { palavras } \\
\text { expressões } \\
\text { utilizado por um } \\
\text { grupo social, nação } \\
\text { ou povo para a } \\
\text { comunicação }\end{array}$ & $\begin{array}{l}\text { língua }: \\
\text { linguado; } \\
\text { linguarudo; } \\
\text { lingüeta }\end{array}$ & \multicolumn{3}{|c|}{$\begin{array}{l}\text { língua } 2 \text { : } \\
\text { língua-alvo; língua- } \\
\text { fonte; língua-padrão; } \\
\text { linguajar }\end{array}$} \\
\hline $\begin{array}{l}\text { pastel }_{1} \text { Comida } \\
\text { salgada ou doce, } \\
\text { feita de massa com } \\
\text { recheio que se frita } \\
\text { em óleo quente }\end{array}$ & $\begin{array}{l}\text { pastel }_{2} \text { : Técnica de } \\
\text { pintura em que se } \\
\text { sobressaem as } \\
\text { tonalidades claras e } \\
\text { suaves }\end{array}$ & $\begin{array}{l}\text { pastel }_{1} \text { : } \\
\text { pastelão; } \\
\text { pastelaria; } \\
\text { pasteleiro }\end{array}$ & \multicolumn{3}{|c|}{$\begin{array}{l}\text { pastel } \mathbf{2} \\
\text { pastelado; pastelista }\end{array}$} \\
\hline \begin{tabular}{l|l} 
pena $_{1 \mathbf{a}}:$ & pena $_{\mathbf{1 b}}:$ \\
Revestim & Peça de \\
ento do & metal \\
corpo & pequena \\
das aves & que é \\
& usada \\
& em uma \\
& caneta \\
& para \\
& escrever
\end{tabular} & \begin{tabular}{|l|l} 
pena $_{2}:$ & pena $_{3}$ : \\
Castigo & Dó que se \\
que se & sente por \\
impõe a a & alguém; \\
alguém & piedade \\
por & \\
alguma & \\
culpa; & \\
punição &
\end{tabular} & $\begin{array}{l}\text { pena }_{1 \mathrm{a}} \text { : } \\
\text { depenar; } \\
\text { despenar } \\
\text { empenar; } \\
\text { penado; } \\
\text { penosa; } \\
\text { penugem }\end{array}$ & & $\begin{array}{l}\text { pena }_{2}: \\
\text { penal }_{2}\end{array}$ & $\begin{array}{l}\text { pena }_{3}: \\
\text { penar; } \\
\text { penoso }\end{array}$ \\
\hline 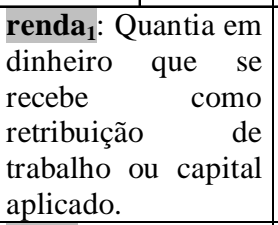 & $\begin{array}{lr}\text { renda }_{2} \text { : } & \text { Tecido } \\
\text { delicado cujos fios } \\
\text { se entrelaçam e } \\
\text { formam desenhos } \\
\text { variados. }\end{array}$ & \multicolumn{2}{|c|}{$\begin{array}{lr}\text { renda }_{1}: & \text { arrendar; } \\
\text { rendar }_{1} ; & \text { rendeira } \\
\text { rendeiro }_{1} ; & \text { rendoso }\end{array}$} & \multicolumn{2}{|c|}{$\begin{array}{l}\text { renda }_{2}: \\
\text { rendar }_{2} ; \\
\text { rendeira }_{2} ; \\
\text { rendeiro } \\
\text { rendilha }\end{array}$} \\
\hline $\begin{array}{l}\text { Soda } 1 \text { Substância } \\
\text { branca e corrosiva } \\
\text { em pedaços ou em } \\
\text { pó usada em } \\
\text { indústrias }\end{array}$ & $\begin{array}{l}\text { Soda }: \text { Bebida não } \\
\text { alcoólica, com gás }\end{array}$ & \multicolumn{2}{|c|}{\begin{tabular}{|l|} 
soda 1 \\
soda $\quad$ cáustica; \\
sodalita; $\quad$ sodamida; \\
sodar; sódico
\end{tabular}} & \multicolumn{2}{|c|}{$\begin{array}{l}\text { soda }_{2}: \\
\text { soda-limonada }\end{array}$} \\
\hline
\end{tabular}




\begin{tabular}{|c|c|c|c|c|c|c|c|}
\hline \multicolumn{2}{|c|}{$\begin{array}{lr}\text { vale }_{1} \text { : } & \text { Espaço, } \\
\text { depressão de terra } \\
\text { entre montanhas ou } \\
\text { quaisquer } \\
\text { superfícies }\end{array}$} & \multicolumn{2}{|c|}{$\begin{array}{l}\text { vale }_{2} \text { : } \\
\text { em pocumento } \\
\text { equivale a dinheiro, } \\
\text { sem formalidade } \\
\text { legal }\end{array}$} & \multicolumn{2}{|c|}{$\begin{array}{ll}\text { vale }_{1} \text { : } & \\
\text { vale anticlinal; } & \text { vale } \\
\text { de lágrimas; } & \text { vale } \\
\text { suspenso; } & \text { vale } \\
\text { fluvial; vale glacial }\end{array}$} & \multicolumn{2}{|c|}{$\begin{array}{l}\text { vale }_{2} \text { : } \\
\text { vale postal; } \\
\text { vale-brinde; } \\
\text { Vale Postal } \\
\text { Nacional }\end{array}$} \\
\hline $\begin{array}{l}\text { venda } \mathbf{a}_{1} \text { Ato } \\
\text { de trocar uma } \\
\text { mercadoria } \\
\text { por dinheiro }\end{array}$ & $\begin{array}{l}\text { vend } \\
\text { de pa } \\
\text { qual } \\
\text { cobre } \\
\text { olhos } \\
\text { impe } \\
\text { visão }\end{array}$ & 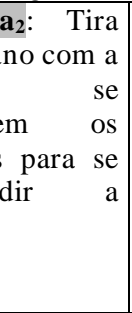 & $\begin{array}{l}\text { venda }_{3} \text { : } \\
\text { Estabelec } \\
\text { i-mento } \\
\text { comercial } \\
\text { no qual } \\
\text { se } \\
\text { vendem } \\
\text { produtos } \\
\text { variados }\end{array}$ & $\begin{array}{l}\text { venda }_{\mathbf{1}}: \\
\text { vendagem } \\
\text { venda direta; } \\
\text { venda casada }\end{array}$ & $\begin{array}{l}\text { vend } \\
\text { vend } \\
\text { vend }\end{array}$ & $\begin{array}{l}\mathbf{a}_{2}: \\
\text { ar; } \\
\text { agem }_{2}\end{array}$ & $\begin{array}{l}\text { venda }_{3}: \\
\text { vendinh } \\
\text { a }\end{array}$ \\
\hline
\end{tabular}

Tabela 2 - Itens homônimos - Campo Léxico

Há casos em que a distinção entre formas homônimas pode evidenciarse por meio do uso de expressões cristalizadas (expressões idiomáticas, locuções) cunhadas com a forma homônima, cujos campos de ação são totalmente disjuntos. Confrontemos:

\begin{tabular}{|c|c|c|c|}
\hline \multicolumn{2}{|c|}{ PARES DE HOMÔNIMOS } & \multicolumn{2}{|c|}{ EXPRESSÃO CRISTALIZADA } \\
\hline $\begin{array}{l}\text { vela1: Objeto de } \\
\text { cera dotado de } \\
\text { pavio que é usado } \\
\text { para iluminar; é } \\
\text { usado, geralmente, } \\
\text { em cerimônias } \\
\text { religiosas, altares, } \\
\text { etc. }\end{array}$ & $\begin{array}{l}\text { vela } 2 \text { Pano (ou } \\
\text { qualquer outro tipo } \\
\text { de material) que, ao } \\
\text { receber o vento, } \\
\text { locomove } \\
\text { embarcações }\end{array}$ & $\begin{array}{l}\text { vela1: } \\
\text { "segurar vela"; } \\
\text { "ficar de vela" }\end{array}$ & $\begin{array}{l}\text { vela2: } \\
\text { "fazer-se à vela"; } \\
\text { "fazer-se de vela"; } \\
\text { "dar velas a", }\end{array}$ \\
\hline $\begin{array}{l}\text { cabo }_{1 \mathbf{b}}: \\
\text { terra }\end{array}$ & $\begin{array}{l}\text { cabo }_{2 \mathrm{a}} \text { : } \\
\text { Extremidade de um } \\
\text { objeto ou } \\
\text { instrumento que } \\
\text { serve para segurá- } \\
\text { lo }\end{array}$ & $\begin{array}{ll}\text { cabo }_{1 \mathbf{b}}: & \\
\text { "Dobrar o cabo"; } \\
\text { "Dobrar o cabo } \\
\text { da } & \text { Boa } \\
\text { Esperança" } & \end{array}$ & $\begin{array}{l}\text { cabo }_{2 \mathrm{a}}: \\
\text { "de cabo a cabo"; } \\
\text { "de cabo a rabo", }\end{array}$ \\
\hline $\begin{array}{l}\text { dado: } \text { Cubo que } \\
\text { possui em cada } \\
\text { uma de suas faces } \\
\text { um número de } 1 \text { a } 6 \\
\text { que serve para } \\
\text { jogar }\end{array}$ & $\begin{array}{lrr}\text { dado2: } & \text { Elemento } \\
\text { ou quantidade } \\
\text { conhecida } & \text { que } \\
\text { serve para } & \text { a } \\
\text { resolução de } & \text { um } \\
\text { problema } & & \\
\end{array}$ & $\begin{array}{l}\text { dado: } \\
\text { "lançar os dados" }\end{array}$ & $\begin{array}{l}\text { dadon: }_{2} \text { "dado que" } \\
\text { "date }\end{array}$ \\
\hline
\end{tabular}

Tabela 3 - Itens homônimos - Expressão Cristalizada

Segundo Gingras (1995), a proposta de distinção entre a homonímia e a polissemia baseada num critério emprestado da lógica, a saber: "o teste de 
coordenação", elucidada por Kempson (1977 apud Gingras 1995) resulta interessante na medida em que é baseado na semântica. O "teste de coordenação" é feito a partir de uma frase: quando for impossível de se utilizar duas formas ambíguas em uma mesma frase sem que haja perda de sentido, trata-se de homonímia; por sua vez, a forma será polissêmica quando for utilizada em uma frase e não ocorrer problemas de significação. Esse critério se aplica somente para palavras que tenham o mesmo comportamento sintático. Segundo Kempson: "os únicos casos de ambigüidade são aqueles em que se trata de homonímia, já que a polissemia não é nada mais do que um caso de sentido mal especificado" (Gingras 1995:98). Gingras, por achar ainda insuficiente esse critério, lança mão da distinção proposta por Geckeler (1976) baseada na proximidade semântica, por meio da teoria dos campos léxicos. E assim, Gingras propõe um critério que se baseia em um modelo psicolingüístico que pretende representar o funcionamento da memória semântica (modelo spreading activation de Quilliam 1962 e 1967 apud Gingras 1995), na medida em que quando uma pessoa ouve ou lê uma palavra, as distintas propriedades do conceito estão ativadas na memória, fato esse que lhe permite entender a palavra ouvida ou lida. Segundo os partidários dessa teoria, pressupõe-se que as propriedades de um conceito não sejam iguais e que existiriam diferenças de acessibilidade. Por conseguinte, a relação que existe entre "pássaro" e "condor" seria mais acessível que a relação existente entre "pássaro" e "pingüim" (Gingras 1995:100), embora todos esses seres sejam considerados "ave”. E assim, Gingras (1995) aplica esse critério a palavras ambíguas e acredita poder explicar porque uma forma, que é classificada de ambígua, não é julgada sempre do mesmo modo por um interlocutor nativo. Com efeito, esse interlocutor seria orientado a escolher um ou outro sentido dependendo da "prioridade semântica" que a forma exigiria em um contexto ou outro. A forma ambígua pertenceria a dois campos léxicos de tal sorte distintos, que o interlocutor ativaria a prioridade semântica de um sentido ou de outro, dependendo de seu contexto, acarretando a ausência de ambigüidade.

Com o propósito de oferecermos mais um mecanismo que possa diferençar formas homônimas, esmiuçamos a sua distinção baseada em "traços especificadores". Esses traços servem para singularizar ou precisar os significados de lexias homônimas, e podem ocorrer tanto em nível sintático (processo de combinatória gramatical) como em nível semântico (processo de correlação semântica do item homônimo com itens não-homônimos considerados desambiguadores em contextos específicos). Esse último caso remeteu ao domínio da "colocação".

Evidenciamos a importância do contexto de uso de uma forma homônima, contexto esse que revelará a sua realização como forma1, forma2 ou forma3. 
Partimos do pressuposto de que seja possível individualizar certas combinatórias gramaticais e certas correlações lexicais que sejam capazes de identificar a realização da forma homônima de maneira única, neutralizando sua ambigüidade. Como o nosso enfoque é a semântica, detivemo-nos em realizar o levantamento dos traços especificadores somente para o nível semântico. Vejamos 8 :

\section{TRAÇOS ESPECIFICADORES \\ Nível semântico}

\section{banco ${ }_{1}$ :}

Traseiro; do carro; sentar; encosto; de trás; da frente; de praça; de jardim; levantar; arrastar; apanhar; de madeira; de lona; viajar; debaixo do; beirada do; lugar; deitar

\section{cálculo:}

função; erro de; operação; comercial; juros; fazer; valor; risco; técnicas; efetuar; problema; erro de; taxa; matemático; terminar; da área; renda; racional; de custos, ganho; peso; vela 1 :

Na mão; acesa; de altar; apagar; segurar; luz da; de cera; acender; chama da; toco de; queimar

\section{língua 1}

Boca; garganta; introduzir; mostrar; passar; lábios; estalos de; soltar; seca; umedecer; beijos de; debaixo da; de fora; ponta da

\section{banco $_{2}$ :}

Gerente; trabalhar; aviso; central; diretor; ir; dinheiro; financiamento; cheque; lotérico; funcionário; filial do; promoção; o trabalho

número; porcentagem; preço; réguas de; numérico; sistema de

\section{cálculo :}

Remover; vesical; encravado; obstruir; cístico; formação de; renal; doença; estrutura; tipo; biliar

\section{vela}

Vento; navegação a; de barco; no mar; flutuar; içar; barco a

\section{língua ${ }_{2}$ :}

Da comunidade; falada; culta; especialista; portuguesa; viva; oficial; natal; de origem; estrangeira; falar; aprender

Um levantamento exaustivo dessa natureza, por exemplo, permite que seja oferecido como input a um sistema computacional a ocorrência de certas lexias não-ambígüas que legitimará ou desautorizará a ocorrência de uma lexia homônima, dependendo de seu valor semântico em variados contextos de uso. 
Em conformidade, Borba (1996) diz:

Quem se interessa por uma descrição sintático-semântica do léxico não se contenta com uma análise componencial nessa linha ${ }^{9}$, justamente por ela ser incompleta elou superficial. A simples subcategorização não basta para determinar como se dá a dinâmica das relações lexicais. Isso porque os traços de substância léxica são opacos e só se tornam transparentes quando se especificam pela combinação com outros. (Borba 1996:49)

Para Borba (1996), existem mecanismos de compatibilidade e de incompatibilidade que aproximam e afastam os itens em relação aos traços semânticos existentes em cada um deles. Esse mesmo autor conclui, "que a observação das relações entre os itens é um caminho produtivo para se estabelecerem condições de uso. A identidade de oposições faz chegar a contextos específicos" (1996:131).

Neste trabalho, o objeto de estudo central é a homonímia, mais especificamente a homografia. O fenômeno da polissemia é analisado justamente para servir de parâmetro à linha limítrofe do fenômeno da homonímia. Entretanto, definir e caracterizar a polissemia é fator imprescindível para a nossa análise, uma vez que individualizamos no interior do fenômeno da homonímia, a polissemia.

Dessa forma, distribuímos os conceitos de homonímia e polissemia da seguinte maneira na tabela classificatória abaixo:

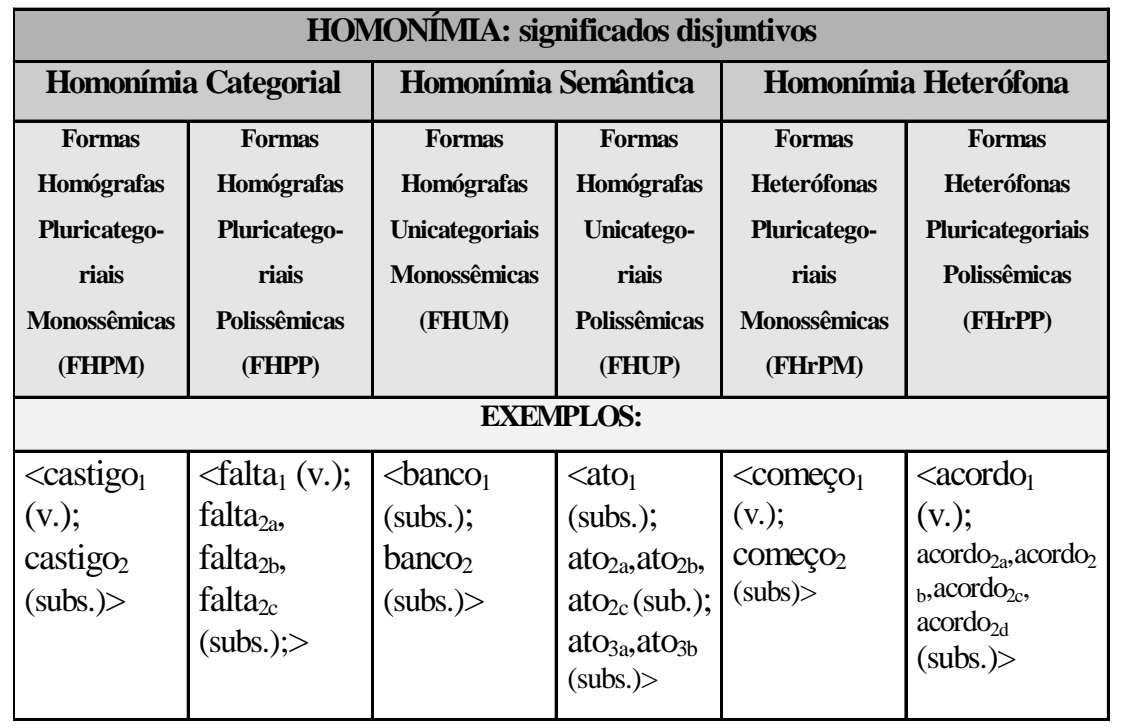

Tabela 4 - Classificação do fenômeno da Homonímia

\footnotetext{
${ }^{9}$ Quer dizer, na linha da semântica lexical que costuma subagrupar o léxico em conjuntos por afinidade de traços do tipo “+movimento, + animado, +concreto", por exemplo (Borba 1996:49).
} 
A partir de tal distribuição, elaboramos os conceitos de tais termos:

Formas Homógrafas Pluricategoriais Monossêmicas (FHPM): formas homógrafas que possuem categorias gramaticais diferentes sendo que cada uma delas possui apenas uma acepção.

Formas Homógrafas Pluricategoriais Polissêmicas (FHPP): formas homógrafas que possuem categorias gramaticais diferentes em que pelo menos uma delas possui mais de uma acepção.

Formas Homógrafas Unicategoriais Monossêmicas (FHUM): formas homógrafas de idêntica categoria gramatical sendo que cada uma delas possui apenas uma acepção.

Formas Homógrafas Unicategoriais Polissêmicas (FHUP): formas homógrafas de idêntica categoria gramatical em que pelo menos uma delas possui mais de uma acepção.

Formas Heterófonas Pluricategoriais Monossêmicas (FHrPM): formas de grafia idêntica, mas que se pronunciam diferentemente sendo que cada uma delas possui apenas uma acepção.

Formas Heterófonas Pluricategoriais Polissêmicas (FHrPP): formas de grafia idêntica, mas que se pronunciam diferentemente em que pelo menos uma delas possui mais de uma acepção.

Dado que entendemos o fenômeno da polissemia como unicategorial, uma forma, se classificada como polissêmica, deverá possuir somente uma categoria gramatical. A partir do momento que a uma forma são atribuídas duas ou mais categorias gramaticais, ela se torna integrante do fenômeno da homonímia. O termo que utilizamos para tal é Forma Unicategorial Polissêmica (FUP), ou seja, uma forma que possui uma categoria gramatical com duas ou mais acepções cujos significados se encontram em conjunção:

\begin{tabular}{|c|}
\hline POLISSEMIA: significados conjuntivos \\
\hline Polissemia Unicategorial \\
\hline $\begin{array}{l}\text { Formas Unicategoriais Polissêmicas } \\
\text { (FUP) }\end{array}$ \\
\hline EXEMPLOS: \\
\hline
\end{tabular}

Tabela 5 - Classificação do fenômeno da Polissemia 


\section{Conclusão}

Pretendemos com esse trabalho realizar uma revisão bibliográfica sobre o fenômeno da homonímia. Com esse objetivo, revisitamos autores que trataram amiúde desse argumento; expusemos suas idéias e suas teorias de forma descritiva e crítica, quando julgamos necessário. Antes de tratarmos, porém, da homonímia, fizemos uma explanação do fenômeno da ambigüidade existente em qualquer e toda língua natural, principalmente daquela ocasionada, justamente, pela homonímia; incluímos, ainda a polissemia em nossa exposição teórica. Vimos que a ambigüidade pode ser causada de maneira natural, na medida em que o emissor de um discurso não tem consciência de estar produzindo um texto ambíguo. Ao contrário, observamos que a ambigüidade pode ser intencional, quando usada como artifício lingüístico para o enriquecimento de contextos especiais. Além disso, revisamos o fenômeno da polissemia com o intuito de podermos traçar pontos limítrofes entre itens polissêmicos e itens homônimos. Nesse sentido, consultamos autores que trataram a polissemia e referimos suas idéias de modo sucinto.

De nossas pesquisas, verificamos que a homonímia é um fenômeno complexo e, ao mesmo tempo, misterioso, na medida em que a sua compreensão e a sua delimitação não são constantes, e nem tampouco contínuas, para os autores consultados. Desta sorte, traçamos parâmetros definitórios para a homonímia com o objetivo de clarearmos as idéias apreendidas dos mais variados autores.

Quando examinamos os critérios distintivos propostos para distinguir a homonímia e a polissemia, mais uma vez constatamos que os autores consultados expunham métodos multifacetados, abordagens teóricas variadas e soluções distintas. Em consonância com alguns autores, validamos critérios de distinção, tais como a análise sêmica. De fato, realizamos uma aplicação dessa análise em itens homônimos do português do Brasil para demonstrar que ela é capaz de sugerir uma distinção entre homônimos, apesar de não ser suficiente. Devido à insuficiência da análise sêmica, fortalecemos um outro critério distintivo, a saber: o campo léxico, sugerido por alguns autores, quando realizamos a sua aplicação também em alguns de nossos pares de homônimos. Essa análise demonstra que é possível distinguirmos itens homônimos através do campo de atuação de cada forma, dado que a forma1 gera e produz itens léxicos totalmente disjuntos daqueles da forma2. Ademais, notamos que essa disjunção do campo de ação de formas homônimas pode se dar no uso de expressões cristalizadas, na medida em que a forma1 fará parte de expressões cujos significados são totalmente independentes das expressões que fazem uso da forma2. Acreditamos que esse possa ser mais 
um critério distintivo entre homônimos, ou seja, a formação de expressões cristalizadas.

Com o escopo de proporcionarmos mais um mecanismo de diferenciação entre formas homônimas, além daqueles já expostos, investigamos formas homônimas a partir de seus singulares "traços especificadores". Esses traços têm o propósito de individualizar e identificar os significados de lexias homônimas, por meio da sua contextualização. De fato, inferimos que uma forma homônima pode ser identificada e desambiguada por meio da sua correlação com outros itens lexicais em um contexto. Esse contexto revelará a realização do homônimo como forma1, forma2 ou forma3. Dessa maneira, realizamos um levantamento (demonstrativo apenas) desses "traços especificadores" em algumas formas homônimas da língua portuguesa do Brasil.

Essa análise nos demonstrou que, de fato, a forma banco1, por exemplo, não ocorreu semanticamente em combinatórias com lexias do tipo "cheque", "dinheiro", "financiamento", etc.; o mesmo se verificou para a forma banco2 que não se realizou semanticamente com "de praça", "de jardim", "levantar", etc. Essa técnica de identificação de itens homônimos, levando em consideração o campo das associações sintagmáticas relativas à experiência de mundo, e a sua conseqüente desambiguação, pode ser empregada por desambiguadores estatísticos, por exemplo, além de parsers, para o Processamento das Línguas Naturais (PLN), na Área da Inteligência Artificial.

E-mail: zavaglia@lem.ibilce.unesp.br Recebido em outubro de 2002 Aprovado em fevereiro de 2003

\section{REFERÊNCIAS BibLIOGRÁFICAS}

Baldinger, K. 1970. Teoría Semántica: Hacia una semántica moderna. Madrid: Ediciones Alcalá.

Barbosa, O. 1987. Dicionário de Homônimos e Parônimos. Brasília: Editerra.

Barbosa, M. A. 1996. Léxico, produção e criatividade: processos do neologismo. 3a.ed. São Paulo: Plêiade.

BerRuto, G. 1979. La Sémantica. México: Editorial Nueva Imagen S.A. Biderman, M.T.C. 1978. Teoria Lingüística: lingüística quantitativa e computacional. Rio de Janeiro: Livros Técnicos e Científicos.

. 1991. Polissemia versus Homonímia. Anais do Seminário do Gel, XXXVIII, Franca: UniFran - União das Faculdades Francanas. . 1998. Dicionário didático de português. 2a. ed. São Paulo: Ática. 
Borba, F. da S. 1996. Uma gramática de valências para o português. São Paulo: Ática.

BréAl, M. 1992. Ensaio de Semântica: Ciência das Significações. Tradução de Férras, A. et al. São Paulo: Educ \& Pontes.

CÂmara JR, J. M. 1985. Estrutura da língua portuguesa. Petrópolis: Vozes. Dias DA Silva, B. C. 1996. A Face Tecnológica dos Estudos da Linguagem: o processamento automático das línguas naturais. Tese de doutorado. Faculdade de Ciências e Letras, Universidade Estadual Paulista, Araraquara.

Chomsky, N. 1959. A Review of B. F. Skinner's Verbal Behavior. Language, 35: $26-58$.

1988. Language and Problems of Knowledge. The MIT Press.

Geckeler, H. 1976. Semántica Estructural y Teoría del Campo Léxico. Madrid: Editorial Gredos.

GingRAS, René. 1995. Para acabar com cierta ambiguedad léxica. Langues e Linguistique, 21. Québec: Université Louval.

Lyons, J. 1987. Semântica - I. Tradução de Averbug, M.W. \& Souza, C. S. Rio de Janeiro: LTC - Livros Técnicos e Científicos Editora S.A.

1977. Linguagem e Lingüística: uma introdução. Tradução de Wanda

Ramos. Lisboa: Editorial Presença/Martins Fontes.

Piatelli-Palmarini, M. (Org.). 1983. Teorias da Linguagem. Teorias da Aprendizagem. São Paulo: Ed. Cultrix.

PotTIER, B. 1968. Lingüística moderna y filologia hispánica. Madrid: Gredos. Rehfeldt, G. K. 1980. Polissemia e campo semântico (estudo aplicado aos verbos de movimento). Porto Alegre: EDURGS/FAPA/FAPCCA.

SABA, A. 1998. Morfosin y Ayda: dos sistemas para analizar textos en lengua espanola. ILC - CNR. (in mimmeo)

Sandmann, A. J. 1990. Polissemia e Homonímia. In: M. H. de M. Neves.

Descrição do Português. Publicação do Curso de Pós-graduação em Lingüística e Língua Portuguesa. Ano IV - Nº 1. UNESP - Campus de Araraquara.

Silva, A. S. da. 1989. Homonímia e Polissemia. Análise sêmica e teoria do campo léxico. Congresso Internacional de Filologia e Lingüística Românica, XIX. Santiago de Compostela.

Skinner, B. F. 1957. Verbal Behavior. Nova York: Appleton-Century-Crofts. Ullmann, S. 1964. Semântica: uma introdução à ciência do significado. Tradução de J. A. Osório Mateus. Lisboa: Fundação Calouste Gulbenkian.

Werner, R. 1982. La Definición Lexicografica. In: G. Haensch et al. La Lexicografía: de la lingüística teórica a la lexicografía práctica. Madrid: Editorial Gredos, S.A. 